\title{
A case study of the highly time-resolved evolution of aerosol chemical and optical properties in urban Shanghai, China
}

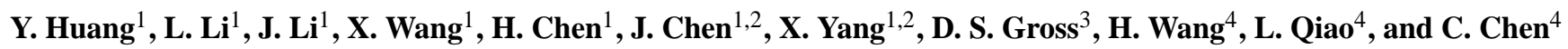 \\ ${ }^{1}$ Shanghai Key Laboratory of Atmospheric Particle Pollution and Prevention, Department of Environmental Science and \\ Engineering, Fudan University, Shanghai 200433, China \\ ${ }^{2}$ Research Institute for Changing Global Environment, Fudan University, Shanghai 200433, China \\ ${ }^{3}$ Department of Chemistry, Carleton College, Northfield, MN 55057,USA \\ ${ }^{4}$ Shanghai Academy of Environmental Sciences, Shanghai 200233, China
}

Correspondence to: X. Yang (yangxin@ fudan.edu.cn)

Received: 6 November 2012 - Published in Atmos. Chem. Phys. Discuss.: 11 December 2012

Revised: 13 March 2013 - Accepted: 27 March 2013 - Published: 17 April 2013

\begin{abstract}
Characteristics of the chemical and optical properties of aerosols in urban Shanghai and their relationship were studied over a three-day period in October 2011. A suite of real-time instruments, including an Aerosol Time-Of-Flight Mass Spectrometer (ATOFMS), a Monitor for AeRosols and GAses (MARGA), a Cavity Ring Down Spectrometer (CRDS), a nephelometer and a Scanning Mobility Particle Sizer (SMPS), was employed to follow the quick changes of the aerosol properties within the $72 \mathrm{~h}$ sampling period. The origin of the air mass arriving in Shanghai during this period shifted from the East China Sea to the northwest area of China, offering a unique opportunity to observe the evolution of aerosols influenced by regional transport from the most polluted areas in China. According to the meteorological conditions and temporal characterizations of the chemical and optical properties, the sampling period was divided into three periods. During Period 1 (00:00-23:00 LT, 13 October), the aerosols in urban Shanghai were mainly fresh and the single scattering albedo varied negatively with the emission of elemental carbon, indicating that local sources dominated. Period 2 (23:00 LT on 13 October to 10:00 LT on 15 October) was impacted by regionally transported pollutants and had the highest particulate matter (PM) mass loading and the lowest particle acidity, characterized by large fractions of aged particles and high secondary ion (nitrate, sulfate and ammonium) mass concentrations. Comparison between ATOFMS particle acidity and quantitative particle acidity by MARGA indicated the significance of semi-quantitative calculation in ATOFMS. Two sub-periods were identified in Pe-
\end{abstract}

riod 2 based on the scattering efficiency of $\mathrm{PM}_{1}$ mass. Period 3 (from 10:00 LT on 15 October to 00:00 LT on 16 October) had a low $\mathrm{PM}_{1} / \mathrm{PM}_{10}$ ratio and a new particle formation event. The comparison of these sub-periods highlights the influence of particle mixing state on aerosol optical properties. We directly observed the influence of regionally transported pollutants on local aerosol properties and demonstrate that the PM mass extinction efficiency is largely determined by the mixing states of the aerosol.

\section{Introduction}

Aerosol particles can scatter and absorb incoming solar radiation as well as outgoing thermal radiation, directly affecting the Earth's radiation budget and hence the global climate (Pöschl, 2005). The direct aerosol radiative forcing is determined by the aerosol number concentration, size distribution and chemical composition (Seinfeld and Pandis, 2006). A high concentration of fine particles can lead to a significant impairment of visibility. Aerosols consisting mostly of inorganic materials (e.g. sea salt (Murphy et al., 1998; Li et al., 2011c), sulfate (Harris and Highwood, 2011), and nitrate (Zhang et al., 2012b) and non-absorbing organic species (e.g. hydrophobic organic compounds, Maria et al., 2004) tend to scatter light, causing a "cooling effect", while those composed mostly of black carbon (BC) (Jacobson, 2001; Kopp and Mauzerall, 2010), soot (Zhang et al., 2008; Monge et al., 2010), mineral dust (Ramanathan et al., 2001; Lelieveld 
et al., 2002; Kaufman et al., 2005), and moderately absorbing organics (Andreae and Gelencsér, 2006; Sun et al., 2007; Wonaschütz et al., 2009; Yang et al., 2009; Nguyen et al., 2012) tend to be absorbing, exerting a "heating effect". According to their distributions of different chemical compositions, aerosols can be divided into external and internal mixtures, with the latter subdivided as homogeneous and heterogeneous mixtures, each of which has different interactions with light (Seinfeld and Pandis, 2006). Chemical compounds with different optical properties, coupled with complex mixing states, collectively increase the intricacies of aerosol and light interactions (Li et al., 2011b). There are growing needs to better understand and measure atmospheric aerosol optical properties. Many studies have investigated the relationship between aerosol chemical and optical properties. For example, the Interagency Monitoring of Protected Visual Environments (IMPROVE) algorithm involving different chemical components with known mass extinction efficiency and hydroscopicity has been adopted by the US Environmental Protection Agency (EPA) for estimating light extinction (Pitchford et al., 2007). Studies in China, like Beijing (Roger et al., 2009; Huang et al., 2010) and the Pearl River Delta (PRD) region (Garland et al., 2008), also contribute to the comprehension of aerosol chemical and optical properties.

Aerosols in the atmosphere evolve and participate in various physical and chemical modifications, e.g. coagulation, gas-to-particle partitioning, aqueous phase processing, and photochemical oxidation (Pöschl, 2005; Robinson et al., 2007; Jimenez et al., 2009). These reactions (also known as "aging") change the reactivity, hygroscopicity, volatility, and likely alter the optical properties of the aerosol (Lelieveld et al., 2002; Kanakidou et al., 2005; Adler et al., 2011; Cappa et al., 2011). To precisely trace the evolution of chemical and optical properties, simultaneous measurements of both chemical and optical properties with high time resolution are required. In the past decade, online aerosol mass spectrometry has made significant contributions to studies of ambient aerosols, allowing particle composition to be correlated with rapid changes in environmental conditions (Pratt and Prather, 2012). For example, Moffet and Prather (2009) developed a single particle mass spectrometry method to simultaneously measure their mixing state and optical properties, concluding that when soot particles were coated by organic carbon or other secondary species, their absorption efficiency was enhanced by a factor of 1.6. Recently, Adler et al. (2011) combined a High-Resolution Aerosol Mass Spectrometer (AMS) and a White Light Aerosol Spectrometer (WELAS) to follow the chemical and optical evolution of biomass burning aerosols, finding a decrease in the overall aerosol absorption and scattering coefficients as the particles are aged through secondary organic aerosol processing. Cappa et al. (2012) used a suite of on-line instruments with high resolution to study the in situ absorption behavior of black carbon (BC) in different mixing states, demonstrating that after $\mathrm{BC}$ particles were coated with organic carbon through photochemical re- actions, no significant absorption enhancement occurred. A series of laboratory studies have been carried out to investigate the coating effect on soot aerosol with different coating materials, such as sulfuric acid (Zhang et al., 2008; Khalizov et al., 2009a, b; Pagels et al., 2009), organic acids (Slowik et al., 2007; Xue et al., 2009a, b) and secondary organic coating (Qiu et al., 2012; Khalizov et al., 2013). These coatings were observed to increase soot particles' hygroscopicity and to effectively enhance their optical properties.

With rapid economic growth and urbanization, megacities in China have experienced severe air pollution problems (Chan and Yao, 2008). The energy consumption of China is increasing at an annual growth rate of as high as $10 \%$. During 2000-2010, the installed capacity of thermal power plants and the vehicle population increased $195 \%$ and $300 \%$, respectively. By the end of 2010, the vehicle population in China exceeded 200 million (Wang and Hao, 2012). Tropospheric $\mathrm{NO}_{2}$ over eastern China, especially above the industrial areas, increased with the fast economic growth, e.g. the growth rate of $\mathrm{NO}_{2}$ column in Shanghai was $20 \% \pm 6 \%$ per year (van der A et al., 2006). The annual average of $\mathrm{PM}_{10}$ (particulate matters with diameters smaller than $10 \mu \mathrm{m}$ ) concentrations in 113 key cities in China was 82 $\mu \mathrm{g} \mathrm{m}^{-3}$, which is about 4-6 times that in the developed countries (Wang and Hao, 2012). Visibility degradation caused by enhanced aerosol concentration has become a pervasive phenomenon in the regions with dense population and fast industrialization (Wang et al., 2009a). Fine particles from anthropogenic emissions, either primary or formed through secondary processes, contribute the most to visibility impairment (Huang et al., 2012a; Yang et al., 2012). Sulfate, nitrate, ammonium, organic matter, and elemental carbon have been identified as the major chemical components in fine particles in Chinese mega-cities and contribute over $90 \%$ of the extinction coefficient (Cao et al., 2012; Wang et al., 2012; Zhang et al., 2012a). However, although the aerosol optical properties were monitored in real time, chemical analysis was performed off-line by collecting filter samples in most of the above studies and particle mixing state was not examined.

In this paper, we deployed a series of high time-resolution instruments focusing on a $72 \mathrm{~h}$ period in which we studied the evolution of the properties of the urban aerosol in the Shanghai atmosphere. We used the Aerosol Time-of-Flight Mass Spectrometer (ATOFMS) to measure the size, chemical composition, and mixing state of individual particles. A Monitor for AeRosols and GAses (MARGA) was also run to quantitatively measure the bulk concentration of particulate inorganic ions. The aerosol optical properties (including scattering and absorption coefficients and single scattering albedo) were monitored by an inhouse-built cavity ringdown spectrometer (CRDS) and an integrating nephelometer. As the fine particles significantly affect atmospheric visibility (Seinfeld and Pandis, 2006), we will emphasize the influence of the evolution of chemical species in fine particles on their optical properties. This is the first report of highly 
time-resolved variations of aerosol optical properties associated with chemical components of single particles in Shanghai.

\section{Experimental}

\subsection{Single particle mass spectrometry}

We used an ATOFMS (TSI 3800, Shoreview, MN, USA) to do single particle size and chemical analysis. Detailed information about the ATOFMS is available in previous publications (Gard et al., 1997; Wang et al., 2010). Briefly, aerosols in the size range of $0.2-2.0 \mu \mathrm{m}$ are effectively drawn from the ambient atmosphere into the vacuum through an aerodynamic focusing lens (Liu et al., 1995a, b). The supersonic expansion accelerates the particles to a terminal size-dependent aerodynamic velocity. This velocity is measured by two orthogonally oriented continuous lasers $(532 \mathrm{~nm})$ fixed at a set distance. Particle size is calculated from the measured speed using a calibration curve generated by monodisperse polystyrene latex spheres (Nanosphere Size Standards, Duke Scientific Corp., Palo Alto, CA, USA) with known diameters $(0.22-2.00 \mu \mathrm{m})$. A pulsed desorption/ionization laser (Qswitched Nd:YAG laser, $266 \mathrm{~nm}$ ) is fired when a particle arrives at the ion source region. Both positive and negative ions are analyzed simultaneously by the time-of-flight mass spectrometer. In this work, the power of the desorption/ionization laser was kept at $\sim 1.0 \mathrm{~mJ}$ per pulse.

All single particle mass spectra acquired were converted into a list of peaks at each $m / z$ using TSI MS-Analyze software with a minimum signal threshold of 30 arbitrary units above the baseline. The resulting peak lists were then imported into YAADA (version 2.11, www.yaada.org), a software toolkit in Matlab (version R2010b) for further analysis of particle sizes and chemical components. In this work, a total of 111678 particles were chemically analyzed (with both positive and negative ion spectra) by the ATOFMS, accounting for about $18 \%$ of all sized particles. Based on the similarities of the mass-to-charge ratio and peak intensity, particles were clustered by using the ART-2a (adaptive resonance theory) (Song et al., 1999) method with a vigilance factor of 0.85 , a learning rate of 0.05 and 20 iterations. The resulting particle clusters were then grouped by hand into 11 general particle types according to mass spectral patterns. The grouped particles accounted for $92.9 \%$ of all the particles with bipolar mass spectra. No significant temporal trend was found for the unclassified particles.

\subsection{Monitor for AeRosols and GAses (MARGA)}

A MARGA (ADI 2080, Applikon Analytical B. B. Corp., The Netherlands) with a $\mathrm{PM}_{2.5}$ cyclone impactor was used to measure particulate water-soluble inorganic ions. The details of MARGA have been described previously (Jongejan et al., 1997; Li et al., 2010; Du et al., 2011; Makkonen et al.,
2012). Briefly, MARGA is composed of two identical sampling boxes and an analytical box. The sampling box consists of two parts: one is a wet rotating denuder (WRD) for absorbing gas $\left(\mathrm{HCl}, \mathrm{HONO}, \mathrm{SO}_{2}, \mathrm{HNO}_{3}, \mathrm{NH}_{3}\right)$ and the other is a steam jet aerosol collector (SJAC) for collecting particles (sampling efficiency of $99.7 \%$ ). Ambient air is drawn at the flow rate of $2 \mathrm{~m}^{3} \mathrm{~h}^{-1}$ through the WRD followed by the SJAC, respectively. The two liquid samples are dissolved in hydrogen peroxide solution and are temporarily stored in syringes $(25 \mathrm{~mL})$ in the analytical box. After filling the syringes for one hour, samples are then injected into the ion chromatograph (IC) in the analytical box. The IC is continuously controlled by an internal calibration method using a standard $\mathrm{LiBr}$ solution. In this work, only the mass concentrations of water-soluble inorganic ions (i.e. $\mathrm{NH}_{4}^{+}, \mathrm{Na}^{+}, \mathrm{K}^{+}$, $\left.\mathrm{Ca}^{2+}, \mathrm{Mg}^{2+}, \mathrm{SO}_{4}^{2-}, \mathrm{NO}_{3}^{-}, \mathrm{Cl}^{-}\right)$in bulk particles were analyzed.

\subsection{Optical measurements}

An inhouse-built cavity ring-down spectrometer (CRDS) was combined with an integrating nephelometer (TSI 3563) and $\mathrm{NO}_{\mathrm{x}}$ analyzer to monitor the optical properties of ambient aerosols. Detailed information about this optical measurement system has been reported ( $\mathrm{Li}$ et al., 2011a). Briefly, two highly-reflective dielectric mirrors $(540 \mathrm{~nm}$ center wavelength, $99.9985 \%$ reflectivity, 6-m radius of curvature, 0.8 inch in diameter, Los Gatos Research, Inc., Mountain View, CA, USA) and a stainless steel cell with two aerosol inlets at both ends and one outlet in the middle formed the cavity. A $0.03 \mathrm{~L} \mathrm{~min}^{-1}$ flow of dry nitrogen is released near the mirrors to prevent particle contamination. The aerosol flow is set to $1 \mathrm{~L} \mathrm{~min}^{-1}$ with a filling length of $58 \mathrm{~cm}$ in the cavity while the entire distance between the two mirrors is $76.4 \mathrm{~cm}$. A light pulse $(532 \mathrm{~nm}, 100 \mu \mathrm{J}$, duration $11 \mathrm{~ns}$ ) produced by a Q-switched pulsed laser (CrystaLaser QG-532-500) is injected into the cavity. Then the intensity of light leaking through one of the mirrors is recorded by a Hamamatsu R928 photomutiplier. Typically, 1000 ring-down traces are averaged to calculate the decay time. The extinction coefficient is determined by Eq. (1),

$C_{\mathrm{ext}}=\frac{L}{l c}\left(\frac{1}{\tau}-\frac{1}{\tau_{0}}\right)$,

where $C_{\text {ext }}$ is the extinction coefficient of particles, $L$ is the length of the cavity, $l$ is the effective length occupied by particles, $c$ is the speed of light, $\tau_{0}$ is the ring-down time of the cavity filled with particle-free air, and $\tau$ is the calculated decay time.

The aerosol scattering coefficient and hemispheric backscattering coefficient is measured by an integrating nephelometer (TSI 3563) at three different wavelengths (450, 550 , and $700 \mathrm{~nm}$ ) with the flow of $5 \mathrm{~L} \mathrm{~min}^{-1}$. Zero adjusting is done automatically every $2 \mathrm{~h}$. Finally, the scattering 
coefficient is calculated at $532 \mathrm{~nm}\left(\alpha_{\text {scat,532) }}\right)$ according to Eq. (2) (Anderson and Ogren, 1998),

$\alpha_{\text {scat }, 532}=\alpha_{\text {scat }, \tau}\left(\frac{532}{\tau}\right)^{-\stackrel{a}{ }}$,

where $\alpha_{\text {scat, } \lambda}$ is the scattering coefficient at the wavelength of $\lambda$ and $\stackrel{a}{a}$ is the Ångström exponent. The single scattering albedo $\omega_{0}$ is the ratio of the scattering coefficient to the extinction coefficient at a given wavelength (in this paper the default wavelength is $532 \mathrm{~nm}$ ):

$\omega_{0}=\frac{\alpha_{\text {scat }}}{\alpha_{\text {ext }}}$.

The absorption $\left(\alpha_{\text {abs }}\right)$ and scattering $\left(\alpha_{\text {scat }}\right)$ coefficients combine to make the extinction coefficients $\left(\alpha_{\text {ext }}\right)$ according to Eq. (4):

$\alpha_{\text {ext }}=\alpha_{\text {abs }}+\alpha_{\text {scat }}$.

As the most important atmospheric gas phase absorber at $532 \mathrm{~nm}, \mathrm{NO}_{2}$ correction in the aerosol extinction coefficient measurement should be considered. $\mathrm{NO}_{2}$ concentration (as shown in Fig. S1) was measured by a $\mathrm{NO}_{\mathrm{x}}$ analyzer (Model $42 \mathrm{i}$, Thermo Scientific) through a separate inlet. The absorption cross-section of $\mathrm{NO}_{2}$ at $1 \mathrm{~atm}$ and $298 \mathrm{~K}$ for $532 \mathrm{~nm}$ is given as $0.35 \mathrm{Mm}^{-1} \mathrm{ppb}^{-1}\left(1.45 \times 10^{-19} \mathrm{~cm}^{2} \mathrm{molec}^{-1}\right)$ (Osthoff et al., 2006). During CRDS measurement, $\tau_{0}$ was measured once per day using particle-free air. The $\mathrm{NO}_{2}$ concentration at this time was converted to absorption coefficient and set as a reference for future $\mathrm{NO}_{2}$ correction. The uncertainty of $\mathrm{NO}_{\mathrm{x}}$ concentration is $\pm 0.4 \mathrm{ppb}$, equivalent to $0.14 \mathrm{Mm}^{-1}$ in the extinction coefficient uncertainty.

\subsection{Sampling period and site}

The sampling lasted for 72 consecutive hours during 13-15 October 2011. The instruments were operated in the building of the Department of Environmental Science and Engineering, Fudan University (FDU, $31^{\circ} 14^{\prime} \mathrm{N}, 121^{\circ} 29^{\prime} \mathrm{E}$ ) in urban Shanghai, close to both residential and traffic emissions sources. Aerosols were transferred to the instruments through a $6 \mathrm{~m}$ long stainless steel pipe $(45 \mathrm{~mm}$ inner diameter) with the inlet $2 \mathrm{~m}$ above the roof of the building. A cyclone pump was used to pull air through the sampling system at $30 \mathrm{~L} \mathrm{~min}^{-1}$, minimizing particle residence time in the sampling line. Aerosols were dried by diffusion drying tubes before they reached the ATOFMS, MARGA, CRDS, and Nephelometer. The size distribution of the aerosol was monitored by a scanning mobility particle sizer (SMPS, TSI 3936) during the campaign. Local meteorological data including temperature, relative humidity $(\mathrm{RH})$, wind speed and direction, and hourly averaged concentrations of $\mathrm{PM}_{10}, \mathrm{PM}_{2.5}$ and $\mathrm{PM}_{1}$ were provided by the Shanghai Meteorological Bureau (temperature and RH seen in Fig. S2).

\section{Results and discussion}

\subsection{Overview of the meteorology}

Backwards air trajectories were analyzed for each day using the HYSPLIT-4 (Hybrid Single-Particle Lagrangian Integrated Trajectory) Model developed by NOAA/ARL. $48 \mathrm{~h}$ back trajectories of each air mass at $100 \mathrm{~m}$ arrival height were computed every $6 \mathrm{~h}$ for each day ending at 16:00 UTC in Shanghai (GMT +8). As shown in Fig. 1, the origins of air masses arriving at the sampling site changed dramatically during the sampling period. Local wind directions also changed, consistent with variation of the air mass. During the first $19 \mathrm{~h}$ of 13 October 2011, the air mass moved slowly from the East China Sea with an average wind speed of $3 \mathrm{~m} \mathrm{~s}^{-1}$, bringing in clean air to the city. Daily average mass concentrations of $\mathrm{PM}_{1}$ and $\mathrm{PM}_{10}$ were 17 and $21 \mu \mathrm{g} \mathrm{m}^{-3}$, respectively. A drizzle started at 14:30 on 13 October and gradually developed to a heavy shower at around 22:00, causing a dip in the mass concentration of $\mathrm{PM}_{1}$ (Fig. 2a). The rainfall stopped at around 04:00 on 14 October.

Coincident with the rainfall, starting at 23:00 on 13 October, the wind direction changed from east to northwest. The air mass arriving at the sampling site travelled through Jiangsu Province and some industrial sites northwest of Shanghai, which are the most polluted areas in the Yangtze River Delta (Huang et al., 2012b, c), bringing in significant amounts of particulate pollutants. The $\mathrm{PM}_{1}$ mass concentration increased steadily and reached a maximum value of $120 \mu \mathrm{g} \mathrm{m}^{-3}$ at about 22:00 on 14 October. The high $\mathrm{PM}_{1}$ loading lasted until around 10:00 on 15 October. From the latter half of 15 October, the air mass was transported over a long distance from the northwest of China. The average mass concentration of $\mathrm{PM}_{10}$ in this period was $76 \mu \mathrm{g} \mathrm{m}^{-3}$. However, the mass ratio of $\mathrm{PM}_{1}$ to $\mathrm{PM}_{10}$ was relatively low (the average value was 0.35 ), indicating an input of coarse particles. At midday on 15 October, a new particle formation event was identified based on the typical "banana" shape in the two-dimensional contour plots (Fig. 2a) of SMPS measurement versus time (Heintzenberg et al., 2007). New particle formation occurs in two distinct stages, nucleation to form a critical nucleus and then subsequent growth (Zhang, 2010; Zhang et al., 2012c).

Based on the above analysis, we divided the entire sampling time into three time periods, summarized in Table 1. Period 1 (00:00-23:00 LT, 13 October) is relatively clean with an air mass originating from the East China Sea; Period 2 (23:00 LT, 13 October-10:00 LT, 15 October) is impacted by regionally transported pollutants from high emission zones. Period 3 (10:00-24:00 LT, 15 October) is characterized by long-distance transport of coarse particles mixed with a new particle formation event. The quick change in meteorological conditions provided a good opportunity to trace the evolution of aerosols in the Shanghai urban area with highly time-resolved monitors. 
Table 1. The names, start times, end times, and duration of the three periods and four sub-periods.

\begin{tabular}{|c|c|c|c|c|}
\hline & Period 1 & \multicolumn{2}{|c|}{ Period 2} & Period 3 \\
\hline Start Time (local) & 13 Oct, 00:00 & \multicolumn{2}{|c|}{13 Oct, 23:00 } & 15 Oct, $10: 00$ \\
\hline End Time (local) & 13 Oct, 23:00 & \multicolumn{2}{|c|}{15 Oct, 10:00 } & 16 Oct, 00:00 \\
\hline \multirow[t]{2}{*}{ Length (hour) } & 23 & \multicolumn{2}{|c|}{35} & 14 \\
\hline & Period 1a & Period $2 \mathrm{a}$ & Period $2 b$ & Period 3a \\
\hline Start Time (local) & 13 Oct, 00:00 & 14 Oct, 00:00 & 14 Oct, $18: 00$ & 15 Oct, $12: 00$ \\
\hline End Time (local) & 13 Oct, $14: 00$ & 14 Oct, $14: 00$ & 15 Oct, $10: 00$ & 16 Oct, 00:00 \\
\hline Length (hour) & 14 & 14 & 16 & 12 \\
\hline
\end{tabular}

(a)

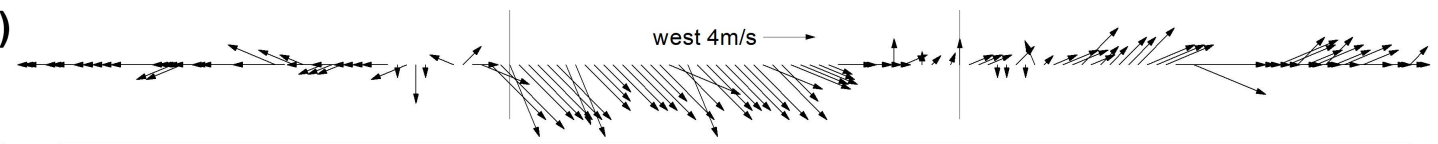

(b)

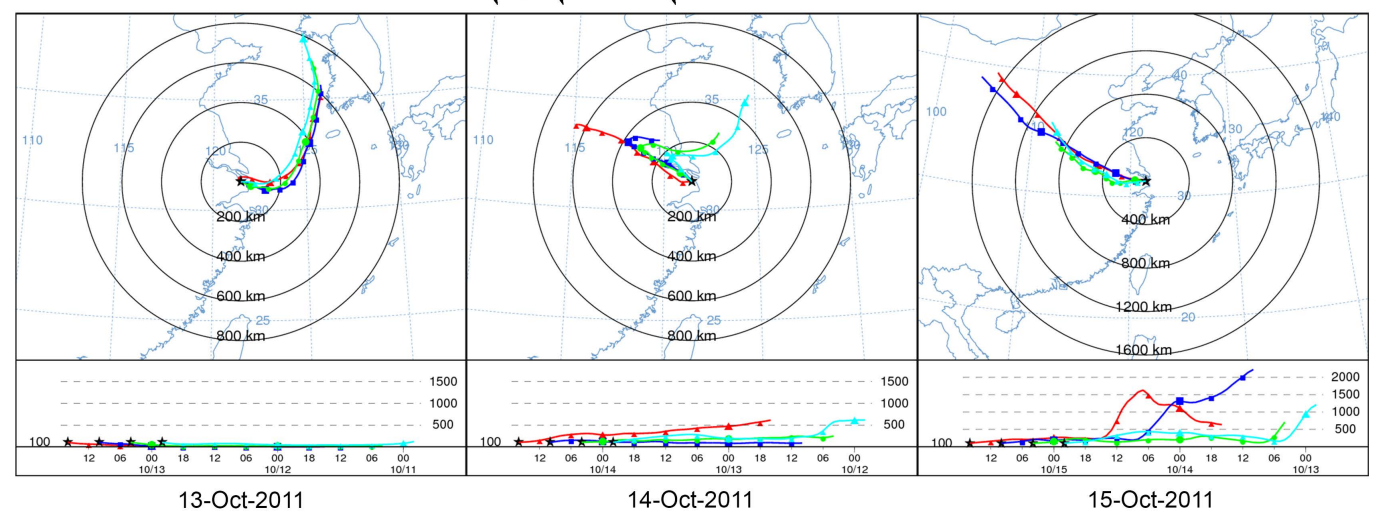

Fig. 1. (a) Temporal wind direction and speed on 13-15 October 2011. (b) Six-hourly resolved $48 \mathrm{~h}$ air mass back trajectories from 13, 14, and 15 October 2011.

\subsection{Temporal variations of chemical and optical properties}

\subsubsection{Particle classification}

Classification of particles analyzed by the ATOFMS can help to elucidate the origins, degree of aging, and mixing state of atmospheric aerosol particles. We classified $92.9 \%$ of all hit particles into 11 groups according to their mass spectral characteristics. The names of these groups and their number fractions are shown in Table 2. The average mass spectral patterns of each group are shown in Figs. S3 and S4. The size distributions and temporal variation of the number fractions of these aerosol types are shown in Fig. 3. The difference between the definition of fresh and aged are the intensities of $m / z-62\left(\mathrm{NO}_{3}^{-}\right)$and $-46\left(\mathrm{NO}_{2}^{-}\right)$in the negative spectra, with the aged groups having stronger signals from both nitrate ions (Moffet et al., 2008). In addition, the appearance

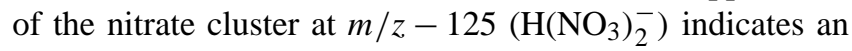
excess of nitrate in all aged aerosol groups. More information about the size distributions of different particle types is presented in the Supplement.
In Period 1 when the air mass came from East China Sea, the total number of particles sized by the ATOFMS was relatively low. The number fractions of fresh $\mathrm{OC}$ and fresh biomass burning types accounted for as high as $60 \%$. Nearly constant particle numbers of the fresh biomass burning particles (shown in Fig. 3b) suggest some stable emission sources around, likely due to harvest-related activities. Compared with Periods 2 and 3, Period 1 had a larger number fraction of the EC type ( $4.2 \%$ versus $1.9 \%$ for Periods $2 \& 3)$ on average. The temporal profile of EC's number fraction had a distinct diurnal pattern peaking at 08:00 (as shown in Fig. 3c), due to the emission from commuter traffic. The freshness of the particles and the diurnal pattern of EC particles suggest that particles in Period 1 were mostly locally emitted.

From the beginning of Period 2, when the wind blew from the northwest, the raw particle counts detected by the ATOFMS jumped to about four times those seen in Period 1. Additionally, the aged particle types (aged biomass burning, OC, ECOC and ammonium) accounted for nearly $70 \%$ in number fraction in Period 2, indicating that more organic species, ammonium and $\mathrm{NO}_{\mathrm{x}}$ pollutants were transported to 


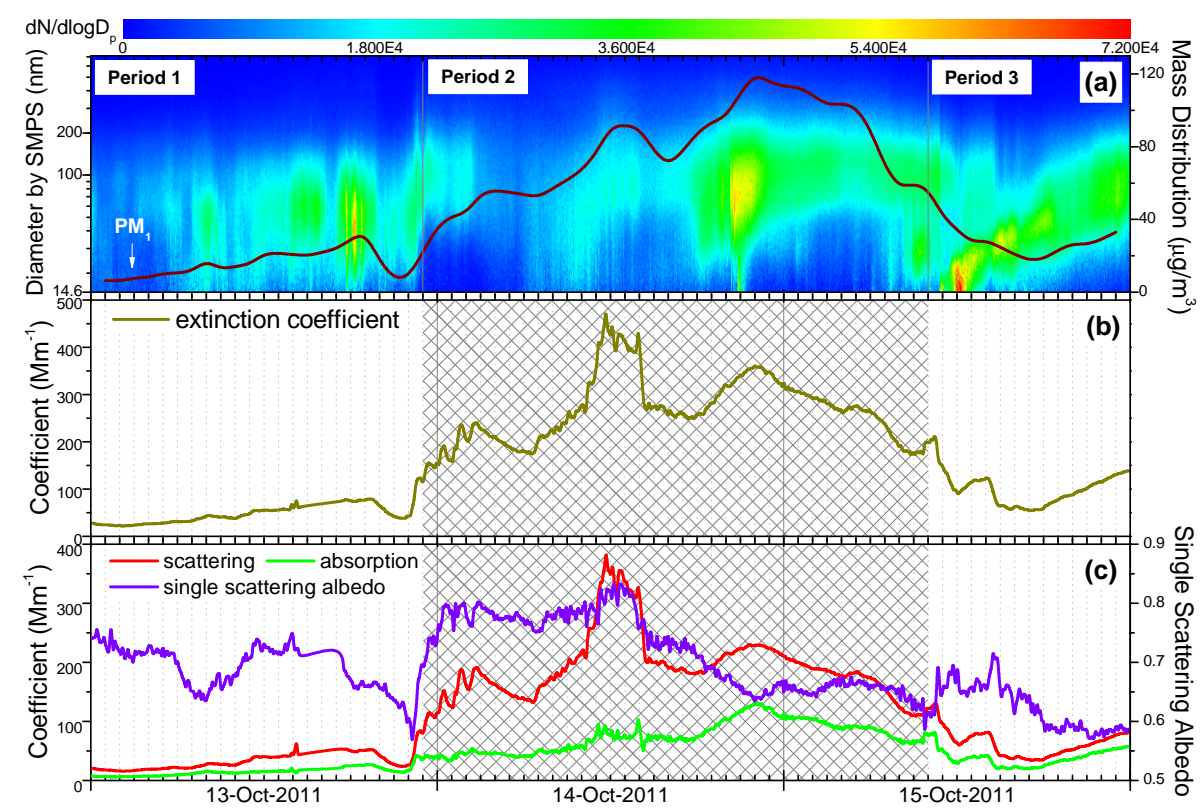

Fig. 2. (a) The number distribution detected by SMPS together with hourly average $\mathrm{PM}_{1}$ mass concentration. (b) The extinction coefficient over the sampling period. (c) The scattering coefficient, absorption coefficient and single scattering albedo over the sampling period.

the sampling site. The fraction of aged OC particles generally exceeded the fresh type in Period 2. However, there was a burst for both the fresh OC and fresh ECOC particles that occurred near 14:00 on 14 October followed by aged OC and aged ECOC peaks, suggesting the photochemical production of secondary organic aerosols. The time delay between the peaks of the fresh and aged types was about $8 \mathrm{~h}$. Ammonium particles accounted for about $25 \%$ of all observed particles and were nearly constant during the entire Period 2. In contrast, the number fraction of ammonium particles in Periods $1 \& 3$ stayed less than $10 \%$. Two distinct peaks in ammonium particles occurred, with one at 00:00 on 14 October and the other around 12:00 on 14 October. The first peak was accompanied by high relative humidity $(\sim 94 \%)$, while the second peak was consistent with the peak of sulfate/nitrate mass spectra and aged OC particles at noon on 14 October.

In Period 3, the number fraction of the fresh biomass type accounted for about $20 \%$ of all particles. Additionally, the number fraction of the fresh OC type exceeded that of the aged OC type. This oscillating transformation of fresh and aged OC clearly shows the evolution of aerosols from regional to local origins. The number fraction of ammonium particles varied similarly with the OC particles. As mentioned above, at the beginning of Period 3 an air parcel carrying coarse particles from the northwest arrived at Shanghai, as indicated by a low $\mathrm{PM}_{1} / \mathrm{PM}_{10}$ value ( $35 \%$, compared with $78 \%$ in Periods 1 and 2). However, no significant increase of dust particle number was recorded by the ATOFMS (observed dust particles only accounted for $2.0 \%$ ) because most dust particles exceeded its sampling size range. For the same reason, a new particle formation event was not observed by
Table 2. Names and fractions of the 11 particle types identified from the ATOFMS data.

\begin{tabular}{lr}
\hline Group & \% of Particles \\
\hline Fresh Biomass Burning (BB) & 4.9 \\
Aged Biomass Burning (BB) & 17.5 \\
Fresh Organic Carbon (OC) & 12.0 \\
Aged Organic Carbon (OC) & 14.6 \\
Fresh Elemental/Organic Carbon (ECOC) & 4.8 \\
Aged Elemental/Organic Carbon (ECOC) & 3.9 \\
Ammonium & 19.3 \\
Na-K-rich & 3.6 \\
Elemental Carbon (EC) & 1.9 \\
Dust & 2.2 \\
Metal & 8.2 \\
\hline Total & 92.9 \\
\hline
\end{tabular}

the ATOFMS, as the particles were below the sampling size range. The newly formed ultrafine particles and their impacts on aerosol optical properties will be discussed below. The temporal profile of the Na-K-rich particle type presented no significant spikes during the whole sampling period, suggesting regional rather than local origins. Discussion of metalcontaining particles is given in the Supplement.

The discussion above reveals that the aerosol types and number concentration depend heavily on the source of the air mass arriving in Shanghai. This observation is consistent with previous studies that show the area to the northwest of Shanghai (i.e. the China Central Plain) is a very polluted region and that the regionally transported pollutants from there 

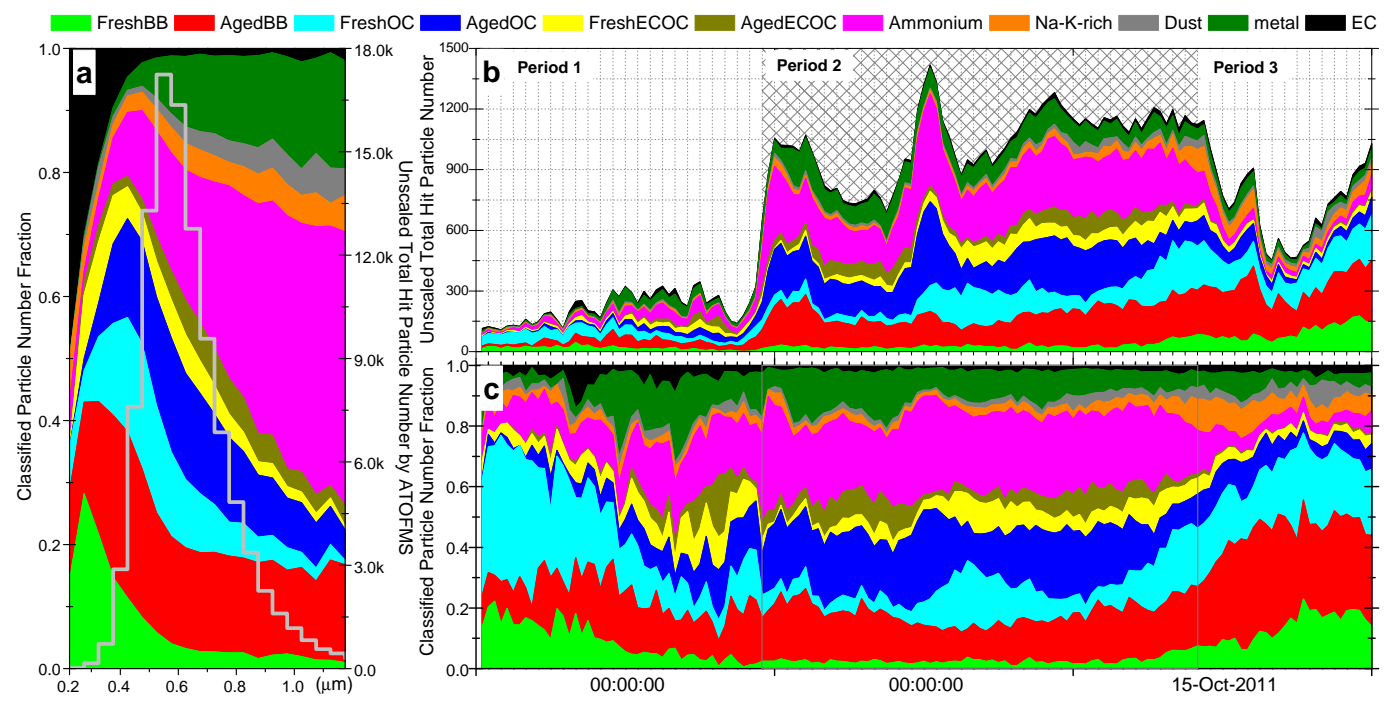

Fig. 3. (a) Chemically resolved size distributions of particle number fractions and the size distribution of unscaled total hit particle number by ATOFMS (gray line). (b) Temporal variation of different particle type counts with 30 min time resolution. (c) Temporal variation of number fractions of different particle types with 30 min time resolution.

can cause a higher $\mathrm{PM}_{1}$ loading in Shanghai (Huang et al., 2012a, c).

\subsubsection{Water soluble inorganic ions in $\mathbf{P M}_{2.5}$}

Figure S5 shows the hourly resolved mass concentrations of $\mathrm{PM}_{2.5}$ water-soluble inorganic ions in this experiment. Nitrate, sulfate, and ammonium reached as high as 40,35 , and $23 \mu \mathrm{g} \mathrm{m}^{-3}$, respectively, during the entire Period 2. These values were approximately 10 times higher than in other time periods, demonstrating the enhanced secondary production during this period, consistent with the observation from the classification of single particles. The mass concentrations of calcium and magnesium jumped suddenly from 0.3 and $0.08 \mu \mathrm{g} \mathrm{m}^{-3}$ to about 1.2 and $0.18 \mu \mathrm{g} \mathrm{m}^{-3}$, respectively, at the beginning of Period 3, corresponding to the time when the air parcel brought dust particles from the northwest of China. Water soluble potassium is often used as a tracer for biomass burning (Du et al., 2011). In this experiment, the mass concentration of water soluble $\mathrm{K}^{+}$varied from 2$4 \mu \mathrm{g} \mathrm{m}^{-3}$. In Periods $1 \& 2$, the temporal profile of water soluble potassium agreed well $\left(R^{2}=0.74\right)$ with that of biomass burning particle-counts from the ATOFMS, further confirming our particle classification. During the entire sampling period (Periods $1-3$ ), $\mathrm{K}^{+}$correlated very well with chlorine $\left(R^{2}=0.85\right)$, suggesting the presence of $\mathrm{KCl}$-containing particles in the atmosphere. The water soluble inorganic ions show clearly that the regionally transported pollutants, especially ammonium, nitrate, and sulfate, have a strong influence on the composition of aerosols in urban Shanghai.

\subsubsection{Profile of aerosol acidity}

Particle acidity is an important parameter related to aerosol chemical and physical properties (Wang et al., 2010; Huang et al., 2012d). One of the classical methods to calculate aerosol acidity is the thermodynamic model ISSORPIA (Nenes et al., 1998; Fountoukis and Nenes, 2007; Guo et al., 2012), which considers a thermodynamic stable state of the main inorganic ions (i.e. $\mathrm{Na}^{+}, \mathrm{K}^{+}, \mathrm{Mg}^{2+}, \mathrm{Ca}^{2+}, \mathrm{NH}_{4}^{+}, \mathrm{NO}_{3}^{-}$, $\left.\mathrm{SO}_{4}^{2-}, \mathrm{Cl}^{-}\right)$in the particle phase. As the major acids and the only base in the atmosphere, the ratio of sulfate and nitrate to ammonium can be used as an indicator to express the relative amount of acids and bases in the particulate phase (He et al., 2012). In the ATOFMS, the ratio of the sum of absolute peak area of $\mathrm{NO}_{3}^{-}$and $\mathrm{HSO}_{4}^{-}$to that of $\mathrm{NH}_{4}^{+}$has been taken as an indicator of particle acidity (Denkenberger et al., 2007). The inset in Fig. 4 shows that particle acidity is closely related to the particle size, and thus the size distribution of these three species could help us to clarify the internal variation of particle acidity (see the discussion and Fig. S6 in the Supplement). The size-resolved particle acidity shows that the highest particle acidity appeared at $\sim 0.28 \mu \mathrm{m}$, and as the particles grew, particle acidity declined. In a similar study by Denkenberger et al. (2007), the maxiuma particle acidity occurred at the diameter of $0.16 \mu \mathrm{m}$, smaller than our observation.

The temporal variation of the ATOFMS particle acidity is plotted in Fig. 4. The color gradient from blue to red indicates the average size of aerosol particles observed with the ATOFMS. The black line is the equivalent charge ratio of major anions $\left(\mathrm{SO}_{4}^{2-}\right.$ and $\left.\mathrm{NO}_{3}^{-}\right)$to cations $\left(\mathrm{NH}_{4}^{+}\right)$from MARGA data (Makkonen et al., 2012). As with the size distribution 


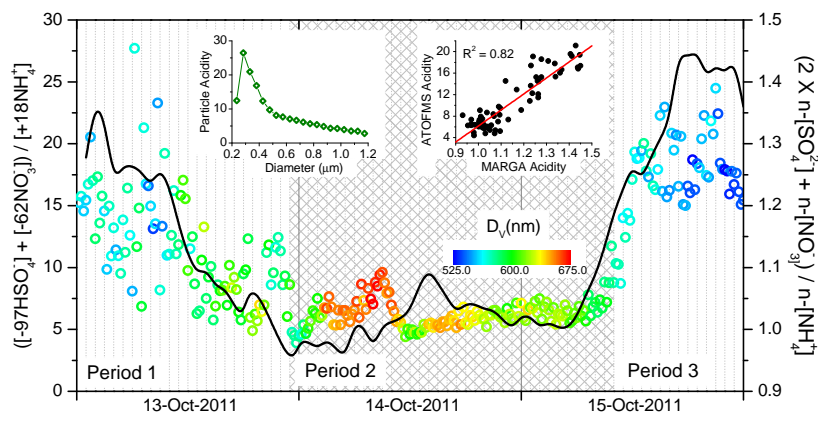

Fig. 4. Particle acidity plotted as a function of time from ATOFMS data with 15 min resolution (circles, left-hand y-axis). The color indicates the average aerodynamic diameter for particles in the 200 $1200 \mathrm{~nm}$ size range detected by ATOFMS. The black line shows MARGA data for particle acidity (right-hand y-axis). The inset: the left shows the size resolved particle acidity from ATOFMS data, averaged over the entire study; the right documents the linear relationship between ATOFMS particle acidity and MARGA particle acidity using the least squares method.

of particle acidity from the ATOFMS, the high bulk particle acidity is consistent with small average particle size. Figure 4 shows the changes of particle acidity and size when the air masses arriving at Shanghai changed, consistent with the three time periods described in this study. During Period 1 , particle size stayed relatively small and particle acidity was fairly high. In Period 2, particle acidity stayed relatively low and constant, while in Period 3 it was high again, especially during the new particle formation event, indicating that aerosols influenced by regionally transported pollutants from the northwest of Shanghai had lower particle acidities and larger particle sizes. Since MARGA can achieve quantitative detection of the concentration of soluble compounds in the particles, the highly-correlated temporal trends of the ATOFMS and MARGA results $\left(R^{2}=0.82\right)$ confirms the validity of the particle acidity calculated from the ATOFMS data.

The equivalent charge ratio of $\left[\mathrm{SO}_{4}^{2-}\right]$ and $\left[\mathrm{NO}_{3}^{-}\right]$to $\left[\mathrm{NH}_{4}^{+}\right]$measured with the MARGA in Period 2 reached about 1.0, indicating that in the particle phase, ammonium neutralized nitric and sulfuric acid. The entirely neutralized conditions in the particle phase suggest the input of particulate ammonium in this episode. Departures from the acidbase ion balance, as seen in Periods $1 \& 3$, suggest that the local atmosphere is deficient in ammonia (Pathak et al., 2009; Wang et al., 2009b), while regional transport during Period 2 brings an ammonia-rich air mass to urban Shanghai. $\mathrm{He}$ et al. (2012) estimated the aerosol acidity of $\mathrm{PM}_{2.5}$ in Beijing using these three inorganic ions and found that the particles in the urban area were more acidic, consistent with our observations. Zhang et al. (2012d) also determined the aerosol acidity in several cities in China and suggested that most urban aerosols were substantially neutralized by local industrial $\mathrm{NH}_{3}$ emissions. Since the cities they investigated are much smaller than the scales of Beijing and Shanghai, where there are no industrial estates releasing ammonia in the central urban area, their conclusion does not conflict with ours. When the air mass carried coarse dust particles to urban Shanghai in Period 3, particles stayed acidic. A low correlation coefficient between $\left[\mathrm{SO}_{4}^{2-}\right]$ and $\left[\mathrm{Ca}^{2+}\right]$ in Period 3 (observed over the entire sampling period) indicates that dust aerosols were of little importance in determining fine particle acidity.

\subsubsection{Evolution of optical properties}

The aerosol optical properties are summarized in Fig. 2. In Period 1, both the mass concentration of particulate matter (PM) and the extinction coefficient were fairly low. About $86 \%$ of the PM mass loading was fine particles $(<2.5 \mu \mathrm{m})$. A minimum in the single scattering albedo $(\sim 0.63)$ occurred at about 08:00 on 13 October, corresponding to the EC peak shown in Fig. 3b. The correlation coefficient between the EC particle number fraction and the single scattering albedo reached about -0.76 , indicating a strong inverse relationship between them. During the rain at around 22:00 on 13 October, all the instruments detected its influence on atmospheric aerosols, showing a quick change of aerosol chemical and physical properties, as seen in Fig. 2 and Fig. 4. After the shower, the air was fairly clean with $\mathrm{PM}_{1}$ levels of only $7.3 \mu \mathrm{g} \mathrm{m}^{-3}$. The single scattering albedo at that time reached about 0.55 , indicating that the absorption coefficient accounted for a significant fraction of extinction coefficient. However, no EC peaks were detected in individual particle mass spectra around that time. This could be explained by the decreased ratio of water-soluble scattering materials like sulfate, nitrate and ammonium which were washed out more effectively by rain. The $\mathrm{PM}_{1}$ mass concentration more than doubled in Period 2, as did the extinction and scattering coefficients, and stayed high until the beginning of Period 3. In Period 2, about $78 \%$ of the $\mathrm{PM}_{10}$ mass loading was due to particles with diameters smaller than $1 \mu \mathrm{m}$, compared with $35 \%$ of that in Period 3. The extinction coefficient was always high during Period 2, while the single scattering albedo in this period actually showed two different patterns. The first $14 \mathrm{~h}$ in Period 2 had high single scattering albedo $(\sim 0.79)$, while from about 18:00 on 14 October it stayed at about 0.66 . During the new particle formation event in Period 3, the values of $\mathrm{PM}_{1}$ loading and the extinction coefficients were much lower, indicating a relatively clean air compared with Period 2.

\subsection{Relationship between optical properties and chemical composition}

The most direct effect of aerosols on people's senses is the degradation of visibility through absorption and scattering of light. The information from the number distribution of 
aerosols determined by the SMPS, hourly averaged $\mathrm{PM}_{1}$ mass concentration, and the extinction $\left(\alpha_{\text {ext }}\right)$, scattering, and absorption coefficients and single scattering albedo recorded by the CRDS and the nephelometer were combined to investigate the variation of aerosol optical properties during this campaign (Fig. 2). Note that relative humidity (RH) also has a profound impact on visibility (Chow et al., 2002a). In our experiment, aerosols passed through a diffusion drying tube before the measurement of optical properties, so the discussion excludes the influence of RH on the aerosol optical properties.

Mie theory describes the absorption and scattering behavior of particles with particle sizes approximately that of the wavelength of incident light. As shown by previous studies, the highest particulate mass extinction efficiency lies in the size range of $0.1-1.0 \mu \mathrm{m}$, the range described by the $\mathrm{PM}_{1}$ mass loading (Seinfeld and Pandis, 2006). In field studies, $\mathrm{PM}_{1}$ has been reported to contribute over $80 \%$ of light extinction (Bergin et al., 2001; Garland et al., 2008). A strong linear correlation can be expected between $\mathrm{PM}_{1}$ mass loading and extinction coefficient. However, the correlations between $\mathrm{PM}_{1}$ mass concentration and extinction coefficient in Periods 1 and 2 were much lower than that for Period 3 (Period 1: 0.65 , Period 2: 0.61 , and Period 3: 0.92). The only reason should be that $\mathrm{PM}_{1}$ with a different mass extinction efficiency was included in the correlation calculation, suggesting that the chemical composition and mixing state of the particles and their variations could also contribute to the extinction coefficient. Knowledge of PM mass loading alone cannot determine the extinction coefficients, given the observed effect of chemical composition.

To investigate the effects of different $\mathrm{PM}_{1}$ chemical compositions on the extinction coefficient during these periods, we identified some consecutive hours in each time period which have nearly constant fractions of major particle types, as shown in Fig. 3c, and single scattering albedo temporal trends, as shown in Fig. 2c. Four new sub-periods were chosen, with one in Period 1, two in Period 2 and one in Period 3, named Period 1a, Period 2a, 2b and Period 3a, respectively. The start and end time for each of these sub-periods is given in Table 1. The fraction of different particle types observed with the ATOFMS during these sub-periods is shown in Fig. 5b. Chemically-resolved size distributions of all particle types and raw particle counts in these four periods are shown in Fig. S7. The linear fits of extinction coefficient versus $\mathrm{PM}_{1}$ mass loading in each of these sub-periods are shown in Fig. 5a. The high correlations $\left(R^{2}=0.90,0.94\right.$, 0.88 , and 0.93 , respectively) are consistent with stable chemical and physical properties of the particles in these timeperiods, which are higher than the $R^{2}$ of the extinction versus $\mathrm{PM}_{1}$ for the whole period, in all cases.

The value of the slope indicates the mass extinction efficiency of the particles. A larger slope means a larger $\mathrm{PM}_{1}$ mass extinction efficiency (Titos et al., 2012; Wang et al., 2012). In order to clarify the relative weight of scattering and (a)

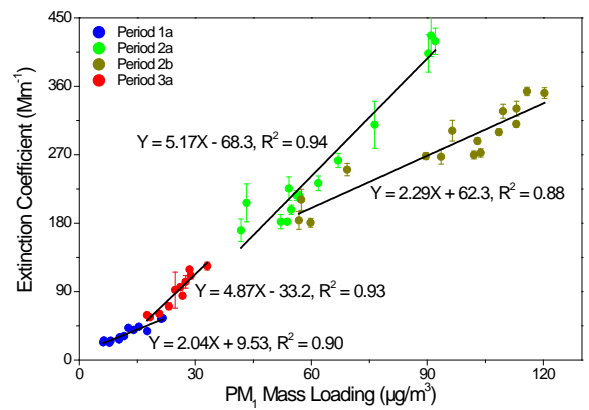

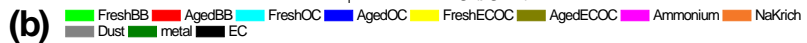

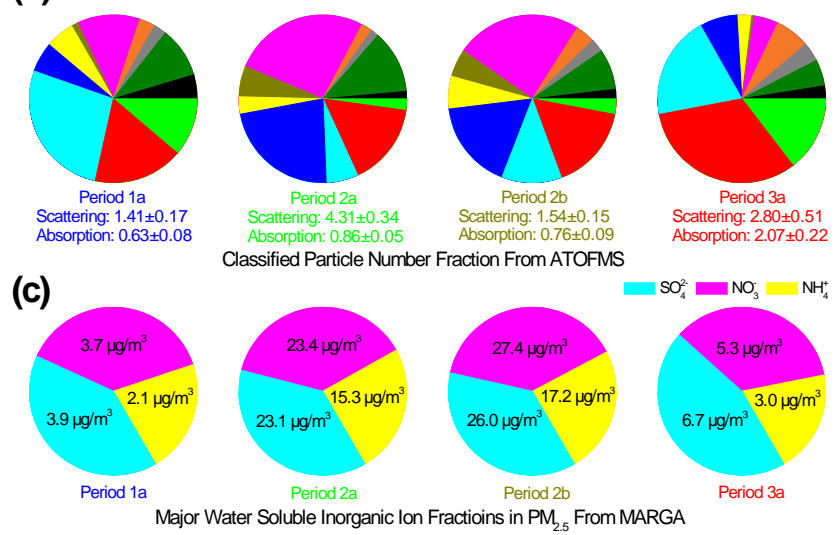

Fig. 5. (a) Extinction coefficient plotted versus $P_{1}$ mass loading with linear fits in the four sub-periods. (b) Average chemically resolved fractions of different particle types from ATOFMS in the four sub-periods. (c) Distributions of water-soluble sulfate, nitrate, and ammonium mass concentrations in $\mathrm{PM}_{2.5}$ from MARGA in the four sub-periods.

absorption in the total mass extinction efficiency, we calculated linear fits of the scattering and absorption coefficients, respectively, with $\mathrm{PM}_{1}$ mass loading (as shown in Table S1 and Fig. 5b). The observed mass extinction efficiencies are comparable with the literature data for urban areas. Mass scattering efficiencies for a variety of cities in North America were reported in the range of $1.7-5 \mathrm{~m}^{2} \mathrm{~g}^{-1}\left(\mathrm{PM}_{2.5}\right)$ by Chow et al. (2002b). Bergin et al. (2001) reported mass scattering efficiencies between 2.3 and $3.6 \mathrm{~m}^{2} \mathrm{~g}^{-1}\left(\mathrm{PM}_{10}\right)$ in Beijing, China. Garland et al. (2008) reported mass scattering efficiencies of $3.60-4.13 \mathrm{~m}^{2} \mathrm{~g}^{-1}\left(\mathrm{PM}_{1}\right)$ and mass absorption efficiencies of $0.78-1.09 \mathrm{~m}^{2} \mathrm{~g}^{-1}\left(\mathrm{PM}_{1}\right)$ near Guangzhou, China.

The mass scattering efficiency of Period 1a $\left(1.41 \pm 0.17 \mathrm{~m}^{2} \mathrm{~g}^{-1}\right)$ was much smaller than that of Period 2a $\left(4.31 \pm 0.34 \mathrm{~m}^{2} \mathrm{~g}^{-1}\right)$. A comparison of particle types observed in these two sub-periods (more aged OC and ammonium particles in Period 2a) indicates that ammonium and nitrate could be the causes of the larger mass scattering and extinction efficiencies in Period 2a. Period 1a and Period 3a both represent relatively clean local air conditions, as discussed above. However, Period $3 \mathrm{a}$ had a higher mass 
extinction efficiency than Period 1a $\left(4.87 \pm 0.53 \mathrm{~m}^{2} \mathrm{~g}^{-1}\right.$ versus $2.04 \pm 0.21 \mathrm{~m}^{2} \mathrm{~g}^{-1}$ ). Both the contributions of scattering and absorption effects on mass extinction efficiency were larger in Period 3a than in Period 1a, with the absorption fraction changing more dramatically. The difference of single scattering albedos in Period 1a and Period 3a, $\sim 0.70$ and $\sim 0.62$, respectively, was mainly caused by the increase in the aerosol's light absorption ability. The large number fraction of biomass burning particles $(47 \%)$ could be the reason for the high mass absorption efficiency in Period 3a (Adler et al., 2011). As discussed above, there was a new particle formation event in Period 3, but the ATOFMS could not follow the chemical evolution of the freshly formed particles. However, previous studies (Seinfeld and Pandis, 2006) have shown that for particles that absorb light, the mass absorption efficiency is nearly constant, independent of particle size, for particles with diameter less than $0.2 \mu \mathrm{m}$, and thus the newly formed small particles could also contribute to the absorption efficiency in Period 3a. The higher number fractions of aged biomass burning and aged OC particles (containing more material such as secondary inorganic salts which scatter efficiently) in Period 3a could be the reason for its higher mass scattering efficiency compared with Period 1a.

The average single scattering albedos of Period 2a and Period $2 \mathrm{~b}$ were 0.79 and 0.66 , respectively. The lower mass extinction efficiency of Period 2b was mostly due to the much weaker particle light scattering ability $\left(1.54 \pm 0.15 \mathrm{~m}^{2} \mathrm{~g}^{-1}\right.$ in Period $2 b$ versus $4.31 \pm 0.34 \mathrm{~m}^{2} \mathrm{~g}^{-1}$ in Period 2a), while their light absorption ability only decreased a little (from $0.86 \pm 0.05 \mathrm{~m}^{2} \mathrm{~g}^{-1}$ to $0.76 \pm 0.09 \mathrm{~m}^{2} \mathrm{~g}^{-1}$ ) compared with Period 2a. Compared with the big differences in composition between Period 1a and Period 3a, Period 2a and Period $2 \mathrm{~b}$ had nearly the same fractions of different particle types, as shown in Fig. 3c. The differential mass spectrum between particles in Period 2a and Period 2b (Fig. S8) shows that the particles in Period 2a contained more inorganic species (ammonium, nitrate, and nitrate cluster) and metals (i.e. potassium, iron, and lead), while the relative intensities of organic ion signals (i.e. $\mathrm{C}_{2} \mathrm{H}_{3}^{+}, \mathrm{C}_{2} \mathrm{H}_{5}^{+}, \mathrm{C}_{3} \mathrm{H}^{+}, \mathrm{C}_{2} \mathrm{H}_{3} \mathrm{O}^{+}$) were $\sim 20 \%$ stronger in Period 2b. The transition between Period 2a and Period $2 b$ occurred at around 14:00 on 14 October, the same time that the peaks of fresh OC and OCEC were observed, suggesting that secondary organic species formed in photochemical reactions could have changed the aerosol mixing state thereafter. Also, the OC/EC ion ratio (Spencer and Prather, 2006) was calculated as a function of size in single particles for these two periods (Fig. S9). Though the two periods had comparable number fraction of carbonaceous particles $(91.2 \%$ and $91.9 \%$ of all detected particles, respectively), particles in Period $2 b$ had a higher OC/EC ratio in the large size range $(>500 \mu \mathrm{m})$. The comparisons here suggest that the secondary organic material coating could lead to a smaller scattering efficiency. Recently, Adler et al. (2011) reported an observation of chemical aging altering aerosol optical properties, in which freshly emitted biomass burning particles became less absorbing after the addition of SOA. In our experiment, most particles in Period 2a were already deeply aged, containing secondary inorganic materials like sulfate and nitrate salts with strong scattering ability. The further chemical aging process (SOA formation) in Period $2 \mathrm{~b}$ covered the particle surfaces with less scattering materials. We also notice that after 18:00 on 14 October, the $48 \mathrm{~h}$ back trajectories changed (as shown in Fig. 1b), which might provide an alternate explanation for the differences between Period 2a and Period 2b.

In long-term bulk measurements, mass fractions of sulfate, nitrate, and ammonium have been the focus when studying the contribution of chemical composition to the aerosol's extinction (scattering) coefficient (Cao et al., 2012; Wang et al., 2012; Zhang et al., 2012a). However, in a highly time resolved short-term experiment like this, average mass fractions cannot offer as much information. Figure $5 \mathrm{c}$ shows the fraction of the average mass concentrations of $\mathrm{SO}_{4}^{2-}, \mathrm{NO}_{3}^{-}$, and $\mathrm{NH}_{4}^{+}$in $\mathrm{PM}_{2.5}$ in the four sub-periods. Particles in Period 2a had almost the same mass fraction of sulfate (37\%), nitrate $(38 \%)$ and ammonium $(25 \%)$ with those of Period $2 \mathrm{~b}(37 \%, 39 \%$, and $24 \%)$ while they had distinct extinction behaviors. This suggests the importance of knowing the particles' mixing state in determining their extinction ability, as discussed above.

The four sub-periods discussed above were characterized by different particle mixing states and chemical components and hence distinct optical properties. In each sub-period, a good correlation between $\mathrm{PM}_{1}$ mass loading and extinction coefficients was observed because of the constant chemical composition and mixing state of the particles, facilitating the prediction of bulk aerosol optical properties. Particles falling in the intervals between these sub-periods were in transition regimes, which caused the worse correlation coefficients for the entire sampling period (as shown in Table 3). Our studies reveal that the highly time-resolved chemical analysis of aerosols can ensure more precise interpretations of aerosol optical properties, compared to the analysis solely based on meteorology and bulk chemical measurements.

\section{Conclusions}

Using high-time-resolution instruments, we investigated the evolution of the chemical and optical properties of $\mathrm{PM}_{1}$ in the Shanghai urban area during a $72 \mathrm{~h}$ sampling period. The air mass which originated from northwest of Shanghai brought a high concentration of particulate matter (PM) containing an increase in ammonium, nitrate and organic carbon species. The ratio of the sum of the absolute peak area of $\mathrm{NO}_{3}^{-}$and $\mathrm{HSO}_{4}^{-}$to that of $\mathrm{NH}_{4}^{+}$in the ATOFMS was used as an indicator of particle acidity and compared with the equivalent charge ratio of $\mathrm{SO}_{4}^{2-}$ and $\mathrm{NO}_{3}^{-}$to $\mathrm{NH}_{4}^{+}$from MARGA data. The temporal profiles of both values showed 
that particle acidity decreased when regionally-transported air mass was present, and revealed that urban areas in megacities like Shanghai have more acidic particles due to a deficiency of ammonia in the atmosphere. The excellent correlation $\left(R^{2}=0.82\right)$ between the ATOFMS particle acidity and the quantitative measurement by MARGA confirms the validity of the ATOFMS ratio of sulfate and nitrate to ammonium as a semi-quantitative measure of particle acidity.

The mass extinction coefficient was used to characterize aerosol optical properties in this work. Our highly timeresolved data showed that the method using PM mass extinction efficiency to assess the atmospheric visibility is only valid when the particle mixing state remains stable. With the help of the ATOFMS, we can identify time periods with constant chemical composition and mixing state of the particles and ensure more precise interpretations of aerosol optical properties. Chemical analysis at the single particle level showed that nitrate and ammonium played important roles in the particle scattering efficiency in Shanghai, while the addition of organic material decreased the scattering efficiency of particles containing scattering materials. In the current study, all the measurements were carried out under dry conditions. The influences of relative humidity on aerosol mixing state and the resulting optical property changes should be considered in future studies.

\section{Supplementary material related to this article is available online at: http://www.atmos-chem-phys.net/13/ 3931/2013/acp-13-3931-2013-supplement.pdf.}

Acknowledgements. This work was supported by The National Natural Science Foundation of China (20937001, 21177027, 41275126) and the Science \& Technology Commission of Shanghai Municipality (12DJ1400100, 10JC1402000). D. G. acknowledges support from Carleton College's Chang-Lan Faculty Development Fund. H. Y. acknowledges support from Fudan Graduate Innovation Fund.

Edited by: K. Schaefer

\section{References}

Adler, G., Flores, J. M., Abo Riziq, A., Borrmann, S., and Rudich, Y.: Chemical, physical, and optical evolution of biomass burning aerosols: a case study, Atmos. Chem. Phys., 11, 1491-1503, doi:10.5194/acp-11-1491-2011, 2011.

Anderson, T. L. and Ogren, J. A.: Determining aerosol radiative properties using the TSI 3563 integrating nephelometer, Aerosol Sci. Tech., 29, 57-69, doi:10.1080/02786829808965551, 1998.

Andreae, M. O. and Gelencsér, A.: Black carbon or brown carbon? The nature of light-absorbing carbonaceous aerosols, Atmos. Chem. Phys., 6, 3131-3148, doi:10.5194/acp-6-3131-2006, 2006.
Bergin, M. H., Cass, G. R., Xu, J., Fang, C., Zeng, L. M., Yu, T., Salmon, L. G., Kiang, C. S., Tang, X. Y., Zhang, Y. H., and Chameides, W. L.: Aerosol radiative, physical, and chemical properties in Beijing during June 1999, J. Geophys. Res.-Atmos., 106, 17969-17980, doi:10.1029/2001jd900073, 2001.

Cao, J. J., Wang, Q. Y., Chow, J. C., Watson, J. G., Tie, X. X., Shen, Z. X., Wang, P., and An, Z. S.: Impacts of aerosol compositions on visibility impairment in Xi' an, China, Atmos. Environ., 59, 559-566, doi:10.1016/j.atmosenv.2012.05.036, 2012.

Cappa, C. D., Che, D. L., Kessler, S. H., Kroll, J. H., and Wilson, K. R.: Variations in organic aerosol optical and hygroscopic properties upon heterogeneous $\mathrm{OH}$ oxidation, J. Geophys. Res.-Atmos., 116, D15204, doi:10.1029/2011jd015918, 2011.

Cappa, C. D., Onasch, T. B., Massoli, P., Worsnop, D. R., Bates, T. S., Cross, E. S., Davidovits, P., Hakala, J., Hayden, K. L., Jobson, B. T., Kolesar, K. R., Lack, D. A., Lerner, B. M., Li, S. M., Mellon, D., Nuaaman, I., Olfert, J. S., Petaja, T., Quinn, P. K., Song, C., Subramanian, R., Williams, E. J., and Zaveri, R. A.: Radiative Absorption Enhancements Due to the Mixing State of Atmospheric Black Carbon, Science, 337, 1078-1081, doi:10.1126/science.1223447, 2012.

Chan, C. K. and Yao, X.: Air pollution in mega cities in China, Atmos. Environ., 42, 1-42, doi:10.1016/j.atmosenv.2007.09.003, 2008.

Chow, J. C., Bachmann, J. D., Wierman, S. S. G., Mathai, C. V., Malm, W. C., White, W. H., Mueller, P. K., Kumar, N., and Watson, J. G.: Visibility: science and regulation, J. Air. Waste. Manage., 52, 973-999, doi:10.1080/10473289.2002.10470844, 2002a.

Chow, J. C., Watson, J. G., Lowenthal, D. H., and Richards, L. W.: Comparability between $\mathrm{PM}_{2.5}$ and particle light scattering measurements, Environ. Monit. Assess., 79, 29-45, doi:10.1023/a:1020047307117, 2002b.

Denkenberger, K. A., Moffet, R. C., Holecek, J. C., Rebotier, T. P., and Prather, K. A.: Real-time, single-particle measurements of oligomers in aged ambient aerosol particles, Environ. Sci. Technol., 41, 5439-5446, doi:10.1021/es0703291, 2007.

Du, H. H., Kong, L. D., Cheng, T. T., Chen, J. M., Du, J. F., Li, L., Xia, X. G., Leng, C. P., and Huang, G. H.: Insights into summertime haze pollution events over Shanghai based on online water-soluble ionic composition of aerosols, Atmos. Environ., 45, 5131-5137, doi:10.1016/j.atmosenv.2011.06.027, 2011.

Fountoukis, C. and Nenes, A.: ISORROPIA II: a computationally efficient thermodynamic equilibrium model for $\mathrm{K}^{+}$$\mathrm{Ca}^{2+}-\mathrm{Mg}^{2+}-\mathrm{NH}_{4}^{+}-\mathrm{Na}^{+}-\mathrm{SO}_{4}^{2-}-\mathrm{NO}_{3}^{-}-\mathrm{Cl}^{-}-\mathrm{H}_{2} \mathrm{O}$ aerosols, Atmos. Chem. Phys., 7, 4639-4659, doi:10.5194/acp-7-4639-2007, 2007.

Gard, E., Mayer, J. E., Morrical, B. D., Dienes, T., Fergenson, D. P., and Prather, K. A.: Real-time analysis of individual atmospheric aerosol particles: Design and performance of a portable ATOFMS, Anal. Chem., 69, 4083-4091, doi:10.1021/ac970540n, 1997.

Garland, R. M., Yang, H., Schmid, O., Rose, D., Nowak, A., Achtert, P., Wiedensohler, A., Takegawa, N., Kita, K., Miyazaki, Y., Kondo, Y., Hu, M., Shao, M., Zeng, L. M., Zhang, Y. H., Andreae, M. O., and Pöschl, U.: Aerosol optical properties in a rural environment near the mega-city Guangzhou, China: implications for regional air pollution, radiative forcing and remote sensing, Atmos. Chem. Phys., 8, 5161-5186, doi:10.5194/acp-8- 
5161-2008, 2008.

Guo, S., Hu, M., Guo, Q. F., Zhang, X., Zheng, M., Zheng, J., Chang, C. C., Schauer, J. J., and Zhang, R. Y.: Primary sources and secondary formation of organic aerosols in Beijing, China, Environ. Sci. Technol., 46, 9846-9853, doi:10.1021/es20425641, 2012.

Harris, B. M. and Highwood, E. J.: A simple relationship between volcanic sulfate aerosol optical depth and surface temperature change simulated in an atmosphere-ocean general circulation model, J. Geophys. Res.-Atmos., 116, D05109, doi:10.1029/2010jd014581, 2011.

He, K., Zhao, Q., Ma, Y., Duan, F., Yang, F., Shi, Z., and Chen, G.: Spatial and seasonal variability of $\mathrm{PM}_{2.5}$ acidity at two Chinese megacities: insights into the formation of secondary inorganic aerosols, Atmos. Chem. Phys., 12, 1377-1395, doi:10.5194/acp12-1377-2012, 2012.

Heintzenberg, J., Wehner, B., and Birmili, W.: 'How to find bananas in the atmospheric aerosol': new approach for analyzing atmospheric nucleation and growth events, Tellus. B, 59, 273-282, doi:10.1111/j.1600-0889.2007.00249.x, 2007.

Huang, K., Zhuang, G. S., Lin, Y. F., Li, J. A., Sun, Y. L., Zhang, W. J., and Fu, J. S.: Relation between optical and chemical properties of dust aerosol over Beijing, China, J. Geophys. Res.-Atmos., 115, D00k16, doi:10.1029/2009jd013212, 2010.

Huang, K., Zhuang, G., Lin, Y., Fu, J. S., Wang, Q., Liu, T., Zhang, R., Jiang, Y., Deng, C., Fu, Q., Hsu, N. C., and Cao, B.: Typical types and formation mechanisms of haze in an Eastern Asia megacity, Shanghai, Atmos. Chem. Phys., 12, 105-124, doi:10.5194/acp-12-105-2012, 2012a.

Huang, X., Song, Y., Li, M. M., Li, J. F., Huo, Q., Cai, X. H., Zhu, T., Hu, M., and Zhang, H. S.: A high-resolution ammonia emission inventory in China, Global Biogeochem. Cy., 26, GB1030, doi:10.1029/2011gb004161, 2012b.

Huang, X.-F., He, L.-Y., Xue, L., Sun, T.-L., Zeng, L.-W., Gong, Z.-H., Hu, M., and Zhu, T.: Highly time-resolved chemical characterization of atmospheric fine particles during 2010 Shanghai World Expo, Atmos. Chem. Phys., 12, 4897-4907, doi:10.5194/acp-12-4897-2012, 2012c.

Huang, Y., Chen, H., Wang, L., Yang, X., and Chen, J.: Single particle analysis of amines in ambient aerosol in Shanghai, Environ. Chem., 9, 202-210, doi:10.1071/en11145, 2012d.

Jacobson, M. Z.: Strong radiative heating due to the mixing state of black carbon in atmospheric aerosols, Nature, 409, 695-697, doi:10.1038/35055518, 2001.

Jimenez, J. L., Canagaratna, M. R., Donahue, N. M., Prevot, A. S. H., Zhang, Q., Kroll, J. H., DeCarlo, P. F., Allan, J. D., Coe, H., Ng, N. L., Aiken, A. C., Docherty, K. S., Ulbrich, I. M., Grieshop, A. P., Robinson, A. L., Duplissy, J., Smith, J. D., Wilson, K. R., Lanz, V. A., Hueglin, C., Sun, Y. L., Tian, J., Laaksonen, A., Raatikainen, T., Rautiainen, J., Vaattovaara, P., Ehn, M., Kulmala, M., Tomlinson, J. M., Collins, D. R., Cubison, M. J., Dunlea, E. J., Huffman, J. A., Onasch, T. B., Alfarra, M. R., Williams, P. I., Bower, K., Kondo, Y., Schneider, J., Drewnick, F., Borrmann, S., Weimer, S., Demerjian, K., Salcedo, D., Cottrell, L., Griffin, R., Takami, A., Miyoshi, T., Hatakeyama, S., Shimono, A., Sun, J. Y., Zhang, Y. M., Dzepina, K., Kimmel, J. R., Sueper, D., Jayne, J. T., Herndon, S. C., Trimborn, A. M., Williams, L. R., Wood, E. C., Middlebrook, A. M., Kolb, C. E., Baltensperger, U., and Worsnop, D. R.: Evolution of organic aerosols in the atmosphere, Science, 326, 1525-1529, doi:10.1126/science.1180353, 2009.

Jongejan, P. A. C., Bai, Y., Veltkamp, A. C., Wyers, G. P., and Slanina, J.: An automated field instrument for the determination of acidic gases in air, Int. J. Environ. Anal. Chem., 66, 241-251, doi:10.1080/03067319708028367, 1997.

Kanakidou, M., Seinfeld, J. H., Pandis, S. N., Barnes, I., Dentener, F. J., Facchini, M. C., Van Dingenen, R., Ervens, B., Nenes, A., Nielsen, C. J., Swietlicki, E., Putaud, J. P., Balkanski, Y., Fuzzi, S., Horth, J., Moortgat, G. K., Winterhalter, R., Myhre, C. E. L., Tsigaridis, K., Vignati, E., Stephanou, E. G., and Wilson, J.: Organic aerosol and global climate modelling: a review, Atmos. Chem. Phys., 5, 1053-1123, doi:10.5194/acp-5-1053-2005, 2005.

Kaufman, Y. J., Koren, I., Remer, L. A., Rosenfeld, D., and Rudich, Y.: The effect of smoke, dust, and pollution aerosol on shallow cloud development over the Atlantic Ocean, P. Natl. Acad. Sci., 102, 11207-11212, doi:10.1073/pnas.0505191102, 2005.

Khalizov, A. F., Xue, H. X., Wang, L., Zheng, J., and Zhang, R. Y.: Enhanced light absorption and scattering by carbon soot aerosol internally mixed with sulfuric acid, J. Phys. Chem. A, 113, 10661074, doi:10.1021/jp807531n, 2009a.

Khalizov, A. F., Zhang, R. Y., Zhang, D., Xue, H. X., Pagels, J., and McMurry, P. H.: Formation of highly hygroscopic soot aerosols upon internal mixing with sulfuric acid vapor, J. Geophys. Res.Atmos., 114, D05208, doi:10.1029/2008jd010595, 2009b.

Khalizov, A. F., Lin, Y., Qiu, C., Guo, S., Collins, D., and Zhang, R.: Role of $\mathrm{OH}$-initiated oxidation of isoprene in aging of combustion soot, Environ. Sci. Technol., 47, 2254-2263, doi:10.1021/es3045339, 2013.

Kopp, R. E. and Mauzerall, D. L.: Assessing the climatic benefits of black carbon mitigation, Proc. Natl. Acad. Sci., 107, 1170311708, doi:10.1073/pnas.0909605107, 2010.

Lelieveld, J., Berresheim, H., Borrmann, S., Crutzen, P. J., Dentener, F. J., Fischer, H., Feichter, J., Flatau, P. J., Heland, J., Holzinger, R., Korrmann, R., Lawrence, M. G., Levin, Z., Markowicz, K. M., Mihalopoulos, N., Minikin, A., Ramanathan, V., de Reus, M., Roelofs, G. J., Scheeren, H. A., Sciare, J., Schlager, H., Schultz, M., Siegmund, P., Steil, B., Stephanou, E. G., Stier, P., Traub, M., Warneke, C., Williams, J., and Ziereis, H.: Global air pollution crossroads over the Mediterranean, Science, 298, 794-799, doi:10.1126/science.1075457, 2002.

Li, H. Y., Han, Z. W., Cheng, T. T., Du, H. H., Kong, L. D., Chen, J. M., Zhang, R. J., and Wang, W. J.: Agricultural fire impacts on the air quality of Shanghai during summer harvesttime, Aerosol Air Qual. Res., 10, 95-101, doi:10.4209/aaqr.2009.08.0049, 2010.

Li, L., Chen, J. M., Chen, H., Yang, X., Tang, Y., and Zhang, R. Y.: Monitoring optical properties of aerosols with cavity ring-down spectroscopy, J. Aerosol. Sci., 42, 277-284, doi:10.1016/j.jaerosci.2011.02.001, 2011a.

Li, W. J., Zhou, S. Z., Wang, X. F., Xu, Z., Yuan, C., Yu, Y. C., Zhang, Q. Z., and Wang, W. X.: Integrated evaluation of aerosols from regional brown hazes over northern China in winter: Concentrations, sources, transformation, and mixing states, J. Geophys. Res.-Atmos., 116, D09301, doi:10.1029/2010jd015099, 2011 b.

Li, Y., Ezell, M. J., and Finlayson-Pitts, B. J.: The impact of organic coatings on light scattering by sodium chloride particles, Atmos. 
Environ., 45, 4123-4132, doi:10.1016/j.atmosenv.2011.05.031, 2011c.

Liu, P., Ziemann, P. J., Kittelson, D. B., and McMurry, P. H.: Generating particle beams of controlled dimensions and divergence: I. Theory of particle motion in aerodynamic lenses and nozzle expansions, Aerosol Sci. Tech., 22, 293-313, doi:10.1080/02786829408959748, 1995a.

Liu, P., Ziemann, P. J., Kittelson, D. B., and McMurry, P. H.: Generating particle beams of controlled dimensions and divergence: II. Experimental evaluation of particle motion in aerodynamic lenses and nozzle expansions, Aerosol Sci. Tech., 22, 314-324, doi:10.1080/02786829408959749, 1995b.

Makkonen, U., Virkkula, A., Mäntykenttä, J., Hakola, H., Keronen, P., Vakkari, V., and Aalto, P. P.: Semi-continuous gas and inorganic aerosol measurements at a Finnish urban site: comparisons with filters, nitrogen in aerosol and gas phases, and aerosol acidity, Atmos. Chem. Phys., 12, 5617-5631, doi:10.5194/acp-125617-2012, 2012.

Maria, S. F., Russell, L. M., Gilles, M. K., and Myneni, S. C. B.: Organic aerosol growth mechanisms and their climate-forcing implications, Science, 306, 1921-1924, doi:10.1126/science.1103491, 2004.

Moffet, R. C. and Prather, K. A.: In-situ measurements of the mixing state and optical properties of soot with implications for radiative forcing estimates, Proc. Natl. Acad. Sci., 106, 11872 11877, doi:10.1073/pnas.0900040106, 2009.

Moffet, R. C., de Foy, B., Molina, L. T., Molina, M. J., and Prather, K. A.: Measurement of ambient aerosols in northern Mexico City by single particle mass spectrometry, Atmos. Chem. Phys., 8, 4499-4516, doi:10.5194/acp-8-4499-2008, 2008.

Monge, M. E., D’Anna, B., Mazri, L., Giroir-Fendler, A., Ammann, M., Donaldson, D. J., and George, C.: Light changes the atmospheric reactivity of soot, Proc. Natl. Acad. Sci., 107, 66056609, doi:10.1073/pnas.0908341107, 2010.

Murphy, D. M., Anderson, J. R., Quinn, P. K., McInnes, L. M., Brechtel, F. J., Kreidenweis, S. M., Middlebrook, A. M., Pósfai, M., Thomson, D. S., and Buseck, P. R.: Influence of sea-salt on aerosol radiative properties in the Southern Ocean marine boundary layer, Nature, 392, 62-65, doi:10.1038/32138, 1998.

Nenes, A., Pandis, S. N., and Pilinis, C.: ISORROPIA: A new thermodynamic equilibrium model for multiphase multicomponent inorganic aerosols, Aquat. Geochem., 4, 123-152, doi:10.1023/a:1009604003981, 1998.

Nguyen, T. B., Lee, P. B., Updyke, K. M., Bones, D. L., Laskin, J., Laskin, A., and Nizkorodov, S. A.: Formation of nitrogenand sulfur-containing light-absorbing compounds accelerated by evaporation of water from secondary organic aerosols, J. Geophys. Res.-Atmos., 117, D01207, doi:10.1029/2011jd016944, 2012.

Osthoff, H. D., Brown, S. S., Ryerson, T. B., Fortin, T. J., Lerner, B. M., Williams, E. J., Pettersson, A., Baynard, T., Dube, W. P., Ciciora, S. J., and Ravishankara, A. R.: Measurement of atmospheric $\mathrm{NO}_{2}$ by pulsed cavity ring-down spectroscopy, J. Geophys. Res.-Atmos., 111, D12305, doi:10.1029/2005jd006942, 2006.

Pagels, J., Khalizov, A. F., McMurry, P. H., and Zhang, R. Y.: Processing of Soot by Controlled Sulphuric Acid and Water CondensationMass and Mobility Relationship, Aerosol Sci. Tech., 43, 629-640, doi:10.1080/02786820902810685, 2009.
Pathak, R. K., Wu, W. S., and Wang, T.: Summertime $\mathrm{PM}_{2.5}$ ionic species in four major cities of China: nitrate formation in an ammonia-deficient atmosphere, Atmos. Chem. Phys., 9, 17111722, doi:10.5194/acp-9-1711-2009, 2009.

Pitchford, M., Malm, W., Schichtel, B., Kumar, N., Lowenthal, D., and Hand, J.: Revised algorithm for estimating light extinction from IMPROVE particle speciation data, J. Air. Waste. Manage., 57, 1326-1336, doi:10.3155/1047-3289.57.11.1326, 2007.

Pratt, K. A., and Prather, K. A.: Mass spectrometry of atmospheric aerosols - Recent developments and applications. Part II: On-line mass spectrometry techniques, Mass. Spectrom. Rev., 31, 17-48, doi:10.1002/mas.20330, 2012.

Pöschl, U.: Atmospheric aerosols: Composition, transformation, climate and health effects, Angew. Chem. Int. Ed., 44, 7520 7540, doi:10.1002/anie.200501122, 2005.

Qiu, C., Khalizov, A. F., and Zhang, R.: Soot aging from $\mathrm{OH}-$ initiated oxidation of toluene, Environ. Sci. Technol., 46, 9464 9472, doi:10.1021/es301883y, 2012.

Ramanathan, V., Crutzen, P. J., Kiehl, J. T., and Rosenfeld, D.: Aerosols, climate, and the hydrological cycle, Science, 294, 2119-2124, doi:10.1126/science.1064034, 2001.

Robinson, A. L., Donahue, N. M., Shrivastava, M. K., Weitkamp, E. A., Sage, A. M., Grieshop, A. P., Lane, T. E., Pierce, J. R., and Pandis, S. N.: Rethinking organic aerosols: Semivolatile emissions and photochemical aging, Science, 315, 1259-1262, doi:10.1126/science.1133061, 2007.

Roger, J. C., Guinot, B., Cachier, H., Mallet, M., Dubovik, O., and Yu, T.: Aerosol complexity in megacities: From sizeresolved chemical composition to optical properties of the Beijing atmospheric particles, Geophys. Res. Lett., 36, L18806, doi:10.1029/2009g1039238, 2009.

Seinfeld, J. H. and Pandis, S. N.: Atmospheric Chemistry and Physics: From air pollution to climate change, 2nd ed. John Wiley \& Sons, New York, 2006.

Slowik, J. G., Cross, E. S., Han, J. H., Kolucki, J., Davidovits, P., Williams, L. R., Onasch, T. B., Jayne, J. T., Kolb, C. E., and Worsnop, D. R.: Measurements of morphology changes of fractal soot particles using coating and denuding experiments: Implications for optical absorption and atmospheric lifetime, Aerosol Sci. Tech., 41, 734-750, doi:10.1080/02786820701432632, 2007.

Song, X. H., Hopke, P. K., Fergenson, D. P., and Prather, K. A.: Classification of single particles analyzed by ATOFMS using an artificial neural network, ART-2A, Anal. Chem., 71, 860-865, doi:10.1021/ac9809682, 1999.

Spencer, M. T. and Prather, K. A.: Using ATOFMS to determine OC/EC mass fractions in particles, Aerosol Sci. Tech., 40, 585594, doi:10.1080/02786820600729138, 2006.

Sun, H. L., Biedermann, L., and Bond, T. C.: Color of brown carbon: A model for ultraviolet and visible light absorption by organic carbon aerosol, Geophys. Res. Lett., 34, L17813, doi:10.1029/2007g1029797, 2007.

Titos, G., Foyo-Moreno, I., Lyamani, H., Querol, X., Alastuey, A., and Alados-Arboledas, L.: Optical properties and chemical composition of aerosol particles at an urban location: An estimation of the aerosol mass scattering and absorption efficiencies, J. Geophys. Res.-Atmos., 117, D04206, doi:10.1029/2011jd016671, 2012. 
van der A, R. J., Peters, D., Eskes, H., Boersma, K. F., Van Roozendael, M., De Smedt, I., and Kelder, H. M.: Detection of the trend and seasonal variation in tropospheric $\mathrm{NO}_{2}$ over China, J. Geophys. Res.-Atmos., 111, D12317, doi:10.1029/2005jd006594, 2006.

Wang, K. C., Dickinson, R. E., and Liang, S. L.: Clear sky visibility has decreased over land globally from 1973 to 2007, Science, 323, 1468-1470, doi:10.1126/science.1167549, 2009a.

Wang, S. X. and Hao, J. M.: Air quality management in China: Issues, challenges, and options, J. Environ. Sci--China, 24, 2-13, doi:10.1016/s1001-0742(11)60724-9, 2012.

Wang, X. F., Gao, S., Yang, X., Chen, H., Chen, J. M., Zhuang, G. S., Surratt, J. D., Chan, M. N., and Seinfeld, J. H.: Evidence for high molecular weight nitrogen-containing organic salts in urban aerosols, Environ. Sci. Technol., 44, 4441-4446, doi:10.1021/es1001117, 2010.

Wang, X. F., Zhang, Y. P., Chen, H., Yang, X., Chen, J. M., and Geng, F. H.: Particulate nitrate formation in a highly polluted urban area: A case study by single-particle mass spectrometry in Shanghai, Environ. Sci. Technol., 43, 3061-3066, doi:10.1021/es8020155, 2009b.

Wang, X. M., Ding, X., Fu, X. X., He, Q. F., Wang, S. Y., Bernard, F., Zhao, X. Y., and Wu, D.: Aerosol scattering coefficients and major chemical compositions of fine particles observed at a rural site hit the central Pearl River Delta, South China, J. Environ. Sci.-China, 24, 72-77, doi:10.1016/s1001-0742(11)607304, 2012.

Wonaschütz, A., Hitzenberger, R., Bauer, H., Pouresmaeil, P., Klatzer, B., Caseiro, A., and Puxbaum, H.: Application of the integrating sphere method to separate the contributions of brown and black carbon in atmospheric aerosols, Environ. Sci. Technol., 43, 1141-1146, doi:10.1021/es8008503, 2009.

Xue, H. X., Khalizov, A. F., Wang, L., Zheng, J., and Zhang, R. Y.: Effects of coating of dicarboxylic acids on the mass-mobility relationship of soot particles, Environ. Sci. Technol., 43, 27872792, doi:10.1021/es803287v, 2009a.

Xue, H. X., Khalizov, A. F., Wang, L., Zheng, J., and Zhang, R. Y.: Effects of dicarboxylic acid coating on the optical properties of soot, Phys. Chem. Chem. Phys., 11, 7869-7875, doi:10.1039/b904129j, 2009b.
Yang, F., Chen, H., Du, J. F., Yang, X., Gao, S., Chen, J. M., and Geng, F. H.: Evolution of the mixing state of fine aerosols during haze events in Shanghai, Atmos. Res., 104, 193-201, doi:10.1016/j.atmosres.2011.10.005, 2012.

Yang, M., Howell, S. G., Zhuang, J., and Huebert, B. J.: Attribution of aerosol light absorption to black carbon, brown carbon, and dust in China - interpretations of atmospheric measurements during EAST-AIRE, Atmos. Chem. Phys., 9, 2035-2050, doi:10.5194/acp-9-2035-2009, 2009.

Zhang, F. W., Xu, L. L., Chen, J. S., Yu, Y. K., Niu, Z. C., and Yin, L. Q.: Chemical compositions and extinction coefficients of $\mathrm{PM}_{2.5}$ in peri-urban of Xiamen, China, during June 2009-May 2010, Atmos. Res., 106, 150-158, doi:10.1016/j.atmosres.2011.12.005, 2012a.

Zhang, H., Shen, Z., Wei, X., Zhang, M., and Li, Z.: Comparison of optical properties of nitrate and sulfate aerosol and the direct radiative forcing due to nitrate in China, Atmos. Res., 113, 113125, doi:10.1016/j.atmosres.2012.04.020, 2012b.

Zhang, R. Y.: Getting to the Critical Nucleus of Aerosol Formation, Science, 328, 1366-1367, doi:10.1126/science.1189732, 2010.

Zhang, R. Y., Khalizov, A. F., Pagels, J., Zhang, D., Xue, H. $\mathrm{X}$., and McMurry, P. H.: Variability in morphology, hygroscopicity, and optical properties of soot aerosols during atmospheric processing, Proc. Natl. Acad. Sci., 105, 10291-10296, doi:10.1073/pnas.0804860105, 2008.

Zhang, R. Y., Khalizov, A., Wang, L., Hu, M., and Xu, W.: Nucleation and growth of nanoparticles in the atmosphere, Chem. Rev., 112, 1957-2011, doi:10.1021/cr2001756, 2012c.

Zhang, X. Y., Wang, Y. Q., Niu, T., Zhang, X. C., Gong, S. L., Zhang, Y. M., and Sun, J. Y.: Atmospheric aerosol compositions in China: spatial/temporal variability, chemical signature, regional haze distribution and comparisons with global aerosols, Atmos. Chem. Phys., 12, 779-799, doi:10.5194/acp12-779-2012, 2012d. 